Article

\title{
The Influence of Effective Microorganisms on Microbes and Nutrients in Kiwifruit Planting Soil
}

\author{
Liangqian Fan ${ }^{1,2,+}, \mathrm{Xi}_{\text {Zhou }}{ }^{2,3,+}$, Yongsheng $\mathrm{Li}^{4,+}$, Lin Ji ${ }^{1,2}$, Guoyan $\mathrm{Wu}^{5}$, Bei Li ${ }^{5}$, \\ Lin Cheng ${ }^{1,2}$, Mei Long ${ }^{5}$, Wenwen Deng ${ }^{5}$ and Likou Zou ${ }^{2,5, *}$ \\ 1 College of Civil Engineering, Sichuan Agricultural University, Dujiangyan 611830, China; \\ flqjacky@163.com (L.F.); jilin_sicau@163.com (L.J.); chl3398@163.com (L.C.) \\ 2 Sichuan Higher Education Engineering Research Center for Disaster Prevention \\ and Mitigation of Village Construction, Sichuan Agricultural University, Dujiangyan 611830, China; \\ zhouxiyeyu@163.com \\ 3 College of Environmental Sciences, Sichuan Agricultural University, Chengdu 611130, China \\ 4 College of Forestry, Henan Agricultural University, Zhengzhou 450000, China; lyshny81@yahoo.com \\ 5 Laboratory of Microbiology, Dujiangyan Campus, Sichuan Agricultural University, Dujiangyan 611830, \\ China; guoyanw90@163.com (G.W.); libeilipei@163.com (B.L.); longzm1110@163.com (M.L.); \\ dwenwen130@163.com (W.D.) \\ * Correspondence: zoulikou@sicau.edu.cn; Tel.: +86-28-8712-7472 \\ + These authors contributed equally to this work.
}

Academic Editor: Chih-Ching Huang

Received: 5 May 2016; Accepted: 25 May 2016; Published: 2 June 2016

\begin{abstract}
To understand the effects of effective microorganisms (EMs) containing multiple strains on microbes and nutrients in kiwifruit planting soil, EMs prepared with four different strains were added to kiwifruit planting soil monthly from April to August. The counts of bacteria, fungi, actinomycetes, and total microbes were determined. The $\mathrm{pH}$, total nitrogen (TN), alkali-hydrolyzable nitrogen (A-N), organic matter $(\mathrm{OM})$, available potassium (A-K), and available phosphorus (A-P) of the soil were measured. Results indicated that the counts of bacteria, fungi, actinomycetes, and total microbes reached $60.33 \times 10^{5}, 4.00 \times 10^{5}, 0.92 \times 10^{5}$, and $65.25 \times 10^{5} \mathrm{CFU} / \mathrm{g}$, respectively, in August, all of which were higher than those of the control group (CK). The bacterial count of the experimental group (EG) was higher than that of the CK in August. The pH-values of the EG were always lower than those of the CK. In August, the TN content of the EG was $1.52 \mathrm{~g} / \mathrm{kg}$, which was higher than that of the CK $(1.35 \mathrm{~g} / \mathrm{kg})$. A significant negative association between the actinomycetes count and TN $(p<0.05)$ was found. For A-N and OM, the content of the EG (A-N, $125.18 \mathrm{mg} / \mathrm{kg} ; \mathrm{OM}, 49.84 \mathrm{mg} / \mathrm{kg}$ ) was roughly the same as that of the CK (A-N, $112.51 \mathrm{mg} / \mathrm{kg}$; OM, $53.11 \mathrm{mg} / \mathrm{kg})$ in August. However, the A-K and A-P contents of the EG (A-K, $145.25 \mathrm{mg} / \mathrm{kg}$; A-P, $111.25 \mathrm{mg} / \mathrm{kg}$ ) were lower than those of the CK (A-K, $182.52 \mathrm{mg} / \mathrm{kg}$; A-P, $202.19 \mathrm{mg} / \mathrm{kg}$ ) in August. Results show that application of EMs in kiwifruit planting soil can increase the counts of soil microbes and might promote the absorption of major nutrients for kiwifruit tree.
\end{abstract}

Keywords: effective microorganisms; kiwifruit; planting soil; nutrients

\section{Introduction}

Kiwifruit (Actinidia deliciosa) is regarded as a healthy fruit and is becoming more and more popular around the world [1,2]. Kiwifruit is delicious and abundant in vitamin C, catechins, and polyphenolic acids [3-5]. Furthermore, the unique composition of kiwifruit can decrease the risk of cardiovascular disease [6,7]. In China, planting kiwifruit has become a major agricultural economic industry in the Sichuan, Shanxi, Zhejiang, and Jiangxi provinces. Accompanied by the increasing demand of 
kiwifruit in recent years, chemical fertilizers were excessively used to increase the yield of kiwifruit. However, excessive use of chemical fertilizer can cause serious environmental problems [8].

To achieve sustainable agricultural development, effective microorganisms (EMs) are widely used in agricultural planting. Chen et al. (2007) found that phosphobacterium 9320-SD can enhance soil fertility and promote plant growth [9]. Estiken et al. (2010) found that the P, Fe, Zn, K, and Mg availability of strawberry planting soil can be promoted after inoculating Bacillus M3 [10]. Yu et al. (2014) found that B. subtilis BS-15 can increase the overall activity of chestnut soil microbes, maintain soil health, and increase soil fertility [11]. Although the utilization of EMs achieved good effects on planting soil of some crops in previous studies, other initial studies have indicated the limited effect of EMs because of its single component [12]. In view of this, a large member of researchers focused on the application of EMs containing multiple strains to enhance the soil fertility for the planting of various types of crops in recent years [13-17].

However, little is known of the effect of EMs containing multiple strains on the improvement of soil nutrients in kiwifruit planting. Therefore, the objective of the study is to determine the influence of EMs containing four different strains on the microbes and nutrients in kiwifruit planting soil.

\section{Material and Methods}

\subsection{Experimental Area}

The experimental area is located in a kiwifruit plantation $\left(31^{\circ} 44^{\prime} 54^{\prime \prime}-31^{\circ} 02^{\prime} 9^{\prime \prime} \mathrm{N}\right.$, $103^{\circ} 25^{\prime} 42^{\prime \prime}-103^{\circ} 47^{\prime} 0^{\prime \prime}$ E) in Dujiangyan City, Sichuan, China. The area has a subtropical humid climate, and the average annual rainfall is $1243.80 \mathrm{~mm}$. The altitude of the area is $670 \mathrm{~m}$. In this study, an $80-\mathrm{m}^{2}$ plot in the kiwifruit plantation was selected as the experimental area; 15 kiwifruit plants were included in the experimental area. The 15 kiwifruit trees were labeled as No. 1-15, respectively. No. 1-3 were used as control group.

\subsection{Strains and EMs Preparation}

The EMs included B. subtilis, B. stearothermophilus, B. amyloliquefaciens, and Actinobacteria sp. The Bacillus spp. strains were grown at $35^{\circ} \mathrm{C}$ in $10 \mathrm{~mL}$ of beef extract peptone medium (Hangzhou Microbiology Reagent Co., Ltd., Hangzhou, China) in 100-mL flasks for 16-20 h with vigorous shaking. Next, $5 \%(v / v)$ cells were inoculated into $250 \mathrm{~mL}$ of the beef extract peptone medium. Cells were grown at $35^{\circ} \mathrm{C}$ for $18-24 \mathrm{~h}$ and shaken at $180 \mathrm{rpm}$ to obtain an initial population level of $10^{8}-10^{9} \mathrm{CFU} / \mathrm{mL}$. Actinobacteria sp. was grown at $28^{\circ} \mathrm{C}$ in $10 \mathrm{~mL}$ of actinomycetes culture medium (Hangzhou Microbiology Reagent Co., Ltd.) in 100-mL flasks for $72 \mathrm{~h}$ with vigorous shaking. Subsequently, $5 \%(v / v)$ cells were inoculated into $250 \mathrm{~mL}$ of the actinomycetes culture medium. Cells were grown at $28{ }^{\circ} \mathrm{C}$ for $72 \mathrm{~h}$ and shaken at $180 \mathrm{rpm}$. The level of B. subtilis, B. stearothermophilus, B. amyloliquefaciens, and Actinobacteria sp. cultivation reached approximately $\sim 10^{8} \mathrm{CFU} / \mathrm{mL}$, respectively. The EMs were prepared by mixing B. subtilis, B. stearothermophilus, B. amyloliquefaciens, and Actinobacteria sp. at the ratio of 1:1:1:1.

\subsection{Fertilization}

The initial level of microbes in the used EMs was approximately $10^{6}-10^{7} \mathrm{CFU} / \mathrm{mL}$. The roots of each plant in the experiment group (EG) were treated with $4 \mathrm{~L}$ of the used EMs every month from April to August; $4 \mathrm{~L}$ of the diluted medium without microbes was used for the control group (CK). The maintenance and management of kiwifruit trees was performed according to the management standard established by the Sichuan province (Manual for the Production of Green Food "Hongyang" Kiwifruit, DB510824/T 1-2009). 


\subsection{Collection of Soil Samples}

The soil samples were collected in each month (April, May, June, July, and August) before fertilization. The 500-g soil samples from each plant's soil lower layer (approximately $20 \mathrm{~cm}$ deep) were collected in sealing sterile plastic bag [18].

\subsection{Determination of Soil Microbe Counts}

The soil microbe counts were determined by the serial dilution plate count method [19]. Briefly, $10 \mathrm{~g}$ of each sample was serially diluted tenfold in a sterile saline solution $(0.85 \% \mathrm{NaCl})$; $100 \mu \mathrm{L}$ of each dilution was plated on nutrient agar plates to determine the bacterial count. The plates were incubated at $35^{\circ} \mathrm{C}$ overnight. The fungi were cultured in the potato dextrose agar medium, and the actinomycetes were cultured in the actinomycetes culture medium; both cultures were incubated for $72 \mathrm{~h}$ at $28^{\circ} \mathrm{C}$. The counts of bacteria, fungi, actinomycetes, and total microbes were recorded as colony-forming units (CFU/g).

\subsection{Determination of Soil Nutrients}

For soil nutrients, total nitrogen (TN), alkali-hydrolyzable nitrogen (A-N), available phosphorus (A-P), and available potassium (A-K) were measured with Kjeldahl's method, the alkaline hydrolysis diffusion method, the molybdenum-blue method, and the ammonium acetate-flame photometer method, respectively [20]. Organic matter (OM) was measured using Multi N/C 3100 TOC analyzer with HT 1300 Solids module (Analytik Jena AG Multi N/C 3100, Jena, Germany) [21]. Soil pH was measured in a 2.5:1 soil-water suspension using a digital $\mathrm{pH}$ meter (Shanghai Rex Instrument Factory PHB-4, Shanghai, China) [22].

\section{Results}

\subsection{Effects of EMs on Microbe Counts}

The counts of bacteria, fungi, actinomycetes, and total microbes are shown in Figure 1. The bacterial counts of the EG were similar to those of the CK from April to July (Figure 1a). However, the count of the EG sharply increased in August $\left(60.33 \times 10^{5} \mathrm{CFU} / \mathrm{g}\right)$ and was higher than that of the CK $\left(12.00 \times 10^{5} \mathrm{CFU} / \mathrm{g}\right)$. For the actinomycetes (Figure 1b), the count of the EG every month was also higher than that of the CK. However, the actinomycetes count of the EG declined after June and reached a minimum value of $0.92 \times 10^{5} \mathrm{CFU} / \mathrm{g}$ in August. Likewise, the fungal count of the EG was higher than that of the CK for each month (Figure 1c). The fungal count of the EG reached a maximum value of $4.00 \times 10^{5} \mathrm{CFU} / \mathrm{g}$ in August. For the total microbes (Figure 1d), the count of the EG in August $\left(65.25 \times 10^{5} \mathrm{CFU} / \mathrm{g}\right)$ was higher than that of the CK $\left(15.15 \times 10^{5} \mathrm{CFU} / \mathrm{g}\right)$.

\subsection{Effects of EMs on $\mathrm{pH}$ and Soil Nutrients}

The $\mathrm{pH}$-value of the EG was lower than that of the CK for each month (Figure 2a). The $\mathrm{pH}$ of the EG dropped between May and July, but finally increased in August. The maximum value was 6.98 in May; the minimum value was 6.44 in July. The $\mathrm{pH}$ of the CK ranged from 6.87 to 7.22 between April and August. 


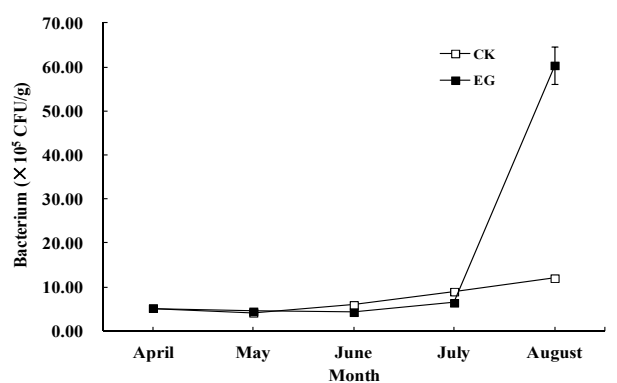

(a)

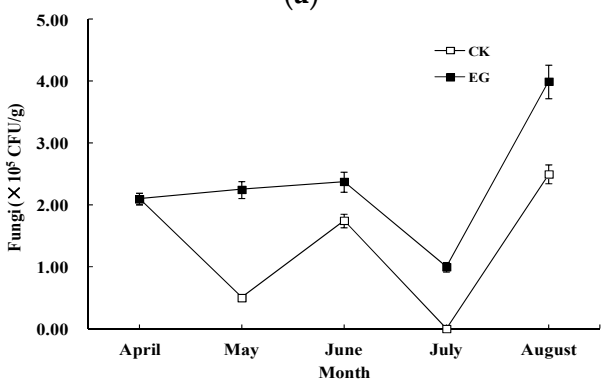

(c)

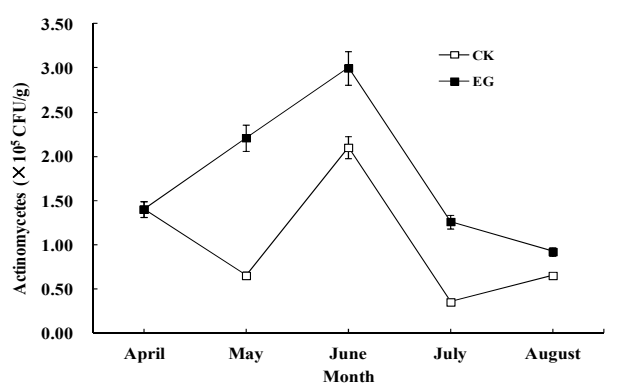

(b)

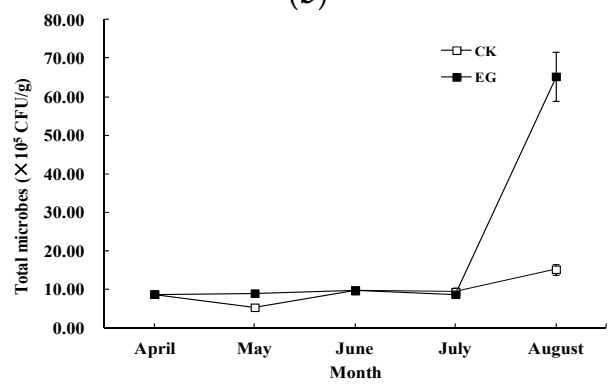

(d)

Figure 1. Changes of microbial counts in kiwifruit planting soil: (a) bacterium; (b) actinomycetes; (c) fungi; and (d) total microbes.

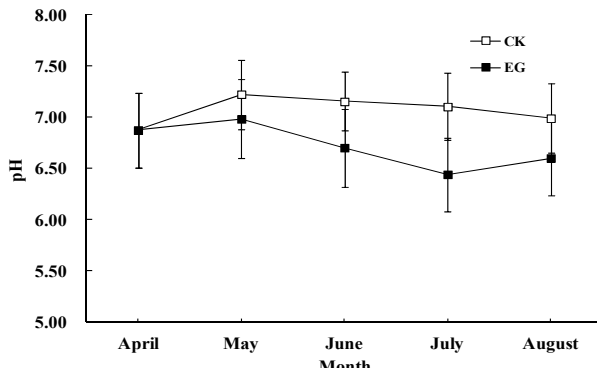

(a)

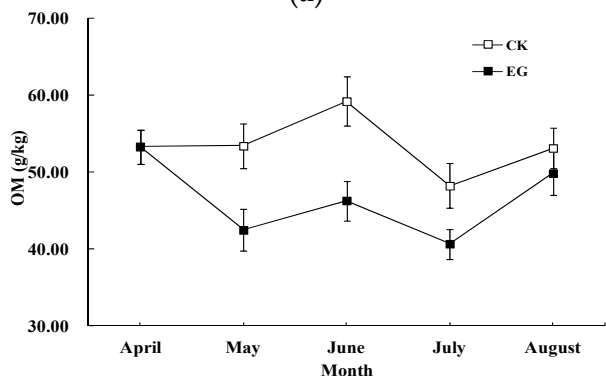

(c)

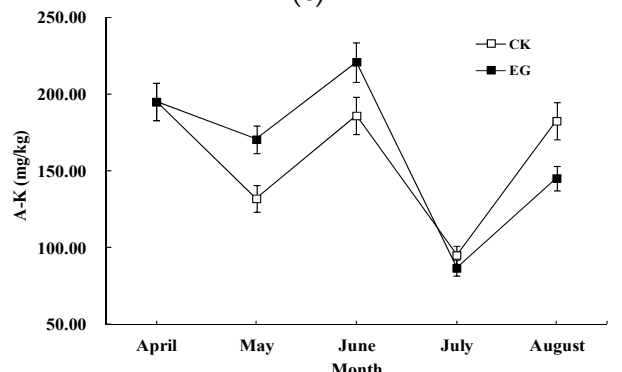

(e)

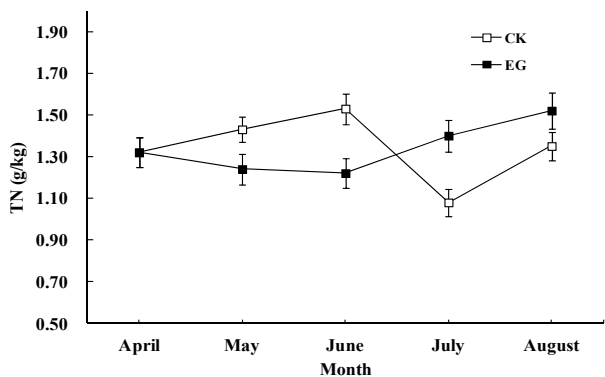

(b)

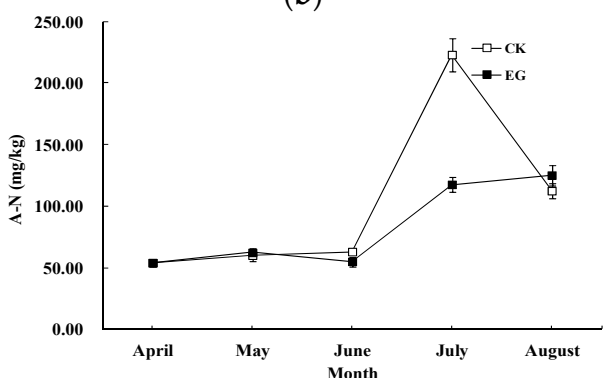

(d)

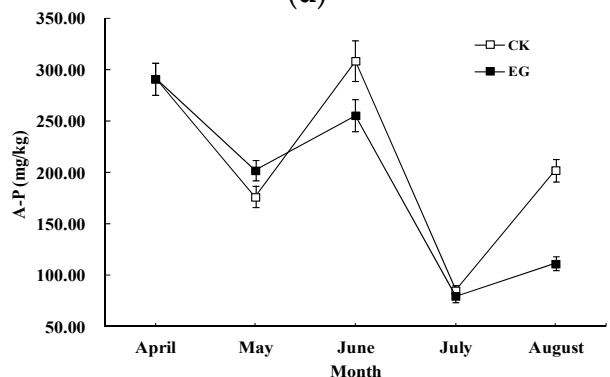

(f)

Figure 2. Changes of $\mathrm{pH}$ and major nutrients in kiwifruit planting soil: (a) $\mathrm{pH}$; (b) TN; (c) $\mathrm{OM}$; (d) A-N; (e) A-K; (f) A-P. 
As shown in Figure 2b, TN was extremely different between the EG and the CK. From April to June, the TN-values of the EG dropped but gradually increased to $1.52 \mathrm{~g} / \mathrm{kg}$ in August. The OM of the EG was similar with that of the CK (Figure 2c). The maximum values were 59.20 and $53.30 \mathrm{~g} / \mathrm{kg}$, and the minimum values were 48.22 and $40.68 \mathrm{~g} / \mathrm{kg}$ for the CK and the EG, respectively. Figure $2 \mathrm{~d}$ indicates that the A-N of the EG increased during the whole experimental period and reached $125.18 \mathrm{mg} / \mathrm{kg}$ in August. The A-N of the CK followed an increasing trend until July and exceeded that of the EG at $105.50 \mathrm{mg} / \mathrm{kg}$ in July, but sharply decreased in August. The value of the EG was higher than that of the CK in August. For A-K (Figure 2e), the change of the EG was consistent with that of the CK. In the EG, the maximum value was $221.00 \mathrm{mg} / \mathrm{kg}$, and the minimum value was $86.73 \mathrm{mg} / \mathrm{kg}$. In the CK, the maximum value was $195.00 \mathrm{mg} / \mathrm{kg}$, and the minimum value was $95.16 \mathrm{mg} / \mathrm{kg}$. The value of A-P is shown in Figure 2f. In the EG, the trend of A-P was similar to that of the CK. The maximum value of the CK was $308.50 \mathrm{mg} / \mathrm{kg}$, and the minimum value was $85.18 \mathrm{mg} / \mathrm{kg}$. The maximum value of the EG was $291.00 \mathrm{mg} / \mathrm{kg}$, and the minimum value was $79.80 \mathrm{mg} / \mathrm{kg}$.

\subsection{Association between Microbes and Soil Nutrients}

The association between bacteria, actinomycetes, fungi, and major soil nutrients in the EG is shown in Table 1 . The absolute values of correlation coefficient $(r)$ of A-N, OM, A-K, and A-P with bacterium were less than 0.70 , thereby indicating the low degree of linear correlation. For TN, $r>0.80$ with bacterium, but $p>0.05$. Therefore, no significant association was found between TN, A-N, OM, $\mathrm{A}-\mathrm{K}, \mathrm{A}-\mathrm{P}$, and the bacterial count $(p>0.05)$. For actinomycetes, the absolute values $(r)$ of $\mathrm{OM}, \mathrm{A}-\mathrm{K}$, and A-P were also less than 0.70 , thereby indicating their weak linear correlation with actinomycetes. Nevertheless, the absolute value $(r)$ of TN and A-N was 0.887 and 0.724 , respectively, but only TN had $p<0.05$. Therefore, no significant association between A-N, OM, A-K, A-P, or the actinomycetes count $(p>0.05)$ was observed, although actinomycetes had a negative significant association with $\mathrm{TN}(p<0.05)$. For fungi, the absolute values $(r)$ of all five indexes were less than 0.70 with $p>0.05$. Therefore, fungi had no significant associations with TN, A-N, OM, A-K, and A-P.

Table 1. Correlation analysis of bacteria, actinomycetes, and fungi between major soil nutrients.

\begin{tabular}{ccccc}
\hline Microbe $(\boldsymbol{y})$ & Soil Nutrients $(\boldsymbol{x})$ & Correlation Equation & $\boldsymbol{r}$ & $\boldsymbol{p}$ \\
\hline \multirow{5}{*}{ Bacteria } & TN & $y=0.004 x+1.272$ & 0.835 & 0.078 \\
& A-N & $y=0.988 x+66.93$ & 0.690 & 0.197 \\
& OM & $y=0.073 x+45.33$ & 0.349 & 0.565 \\
& A-K & $y=-0.477 x+171.3$ & -0.230 & 0.710 \\
& A-P & $y=-1.812 x+217.1$ & -0.494 & 0.398 \\
\hline \multirow{5}{*}{ Actinomycetes } & TN & $y=-0.130 x+1.568$ & $-0.887 *$ & 0.045 \\
& A-N & $y=-30.41 x+136.3$ & -0.724 & 0.166 \\
& OM & $y=-1.570 x+49.27$ & -0.253 & 0.682 \\
& A-K & $y=41.18 x+91.25$ & 0.676 & 0.210 \\
& A-P & $y=60.62 x+81.30$ & 0.562 & 0.325 \\
\hline \multirow{5}{*}{ Fungi } & TN & $y=0.049 x+1.224$ & 0.429 & 0.471 \\
& A-N & $y=6.794 x+66.93$ & 0.206 & 0.740 \\
& OM & $y=2.612 x+40.38$ & 0.542 & 0.346 \\
& A-K & $y=14.42 x+129.8$ & 0.302 & 0.622 \\
& A-P & $y=-1.234 x+190.7$ & -0.015 & 0.981 \\
\hline
\end{tabular}

$r$ : correlation coefficient; ${ }^{*} p<0.05$, significant correlation.

\section{Discussion}

Interestingly, the counts of bacteria and actinomycetes of the EG (Figure 1a,b) were higher than those of the CK because the used EMs contain bacteria and actinomycetes. Likewise, the fungal counts of the EG (Figure 1c) were also higher than those of the $\mathrm{CK}$, which is probably attributed to the decreased soil pH (Figure 2a). Fungi prefer to live in slightly acid soil environments [23]. In general, 
the application of the EMs can eventually increase the counts of bacteria, actinomycetes, and fungi in kiwifruit soil. Based on the observed counts of bacteria, fungi, and actinomycetes, the percentages of all three microbes were calculated (see Table 2). Bacteria is one of major members of soil microbes and plays an important role in promoting organic matter decomposition, accelerating mineral nutrition cycle, maintaining and improving soil fertility [24,25]. As shown in Table 2, the proportion of bacteria was always the highest in the EG and the CK for each month, which indicate that the application of EMs still maintains an important position of bacteria in the kiwifruit planting soil. In addition, as compared with the CK, the proportions of bacteria in the EG were reduced $28.24 \%, 16.90 \%$, and $22.29 \%$ from May to July, respectively. However, the proportions of fungi and actinomycetes in the EG increased $15.54 \%, 6.70 \%$, and $11.53 \%$ and $12.70 \%, 10.20 \%$, and $10.76 \%$ from May to July, respectively. The results show that the application of the EMs can change the biological diversity of the kiwifruit planting soil ecosystem.

Table 2. Percentage of bacteria, fungi, and actinomycetes counts in kiwifruit planting soil.

\begin{tabular}{cccc}
\hline Month & Bacteria (\%) & Fungi (\%) & Actinomycetes (\%) \\
\hline April & 59.76 & 24.17 & 16.07 \\
May (CK) & 78.24 & 9.46 & 12.30 \\
May (EG) & 50.00 & 25.00 & 25.00 \\
June (CK) & 61.00 & 18.00 & 21.00 \\
June (EG) & 44.10 & 24.70 & 31.20 \\
July (CK) & 96.24 & 0.00 & 3.76 \\
July (EG) & 73.95 & 11.53 & 14.52 \\
August (CK) & 79.21 & 16.50 & 4.29 \\
August (EG) & 92.46 & 6.13 & 1.41 \\
\hline
\end{tabular}

CK: control group; EG: experimental group.

In this study, the soil of the EG appeared to have slight $\mathrm{pH}$ variation ( $\mathrm{pH}$ ranged from 6.44 to 6.98; Figure 2a), which indicated that the microbe treatments of planting soil can decrease the soil $\mathrm{pH}$. The decreased $\mathrm{pH}$ may be explained by the production of organic acids, as reported in previous studies $[26,27]$. However, the extent of the $\mathrm{pH}$ reduction of the EG was not obvious, and the $\mathrm{pH}$-values of the EG were still near neutrality.

The addition of EMs can promote the activity of urease and invertase in planting soil, thereby increasing the decomposition of OM and the release of available soil nutrients [28]. Simultaneously, the fruit expanding stage for kiwifruit occurs from April to June in the study area. In this stage, the demand of nitrogen is relatively larger than that of other nutrient elements. Thus, the TN and OM contents of the EG decreased from April to June (Figure 2b,c, respectively). In addition, the A-N content of the EG was slightly lower than that of the CK from April to June. B. subtilis can promote planting upon the absorption of nitrogen and lead to the increase of nitrogen content in plants [29-31]. This result implies that more A-N might be absorbed by the kiwifruit tree after the EMs are added to the planting soil. According to the results, it can be deduced that the EMs can improve the A-N utilization rate in kiwifruit planting soil. The fruit maturity stage for kiwifruit occurs in July and August in the study area. In this stage, more various organic substances are needed to support the growth of kiwifruit. The demand of nitrogen relatively decreases in this stage. Thus, the A-N contents of the EG and the CK increased in July and August (Figure 2d). However, the A-N content of the EG was still obviously lower than that of the CK in July. The result may also be related to the promoting effect of A-N utilization of the EMs. In addition, the previous study reported that the overabundance of soil water content caused by rainfall could have decreased the A-N content [32]. In the experimental period, the rainy season occurred in July; thus, rainwater may also have washed away much A-N in the soil of the EG.

In the study, the A-K-values of the EG were higher than those of the CK during May to June (Figure 2e), which is mainly caused by the function of potassium-dissolving through Bacillus spp. [33]. 
For A-P, the content of the EG was higher than that of the CK in May (Figure 2f). This is perhaps a result of the function of the phosphate solubilizing of Bacillus spp., some of which are able to solubilize $\mathrm{P}$ through acidification or chelation, or enzyme action [33-39]. In Figure 2e,f, the A-P and A-K content followed the same variation trend in both the EG and the CK; the A-P and A-K contents reached their maximum in June, whereas the minimum A-P and A-K contents appeared in July. As discussed earlier, nitrogen is the highest element demanded to expand kiwifruit from April to June. The demands of potassium and phosphorus are not the highest in this stage. Therefore, the A-P and A-K contents improved with the passage of time from April to June in the EG and the CK. On the contrary, July and August are the main period of transformation of $\mathrm{OM}$ and formation of the quality of kiwifruit. In this period, the potassium and phosphorus demands increase. This led to the decrease of A-K and A-P in July and August in both the EG and the CK. Moreover, the A-K and A-P contents of the EG were lower than those of the CK in July and August. B. subtilis can promote planting upon absorption of potassium and phosphorus [29-31], and B. amyloliquefaciens can promote planting upon absorption of phosphorus $[38,39]$. Thus, the results show that the EMs applied in the study might promote the absorption of potassium and phosphorus for kiwifruit planting.

Our study found that the count of actinomycetes had significant negative correlation with TN content $(p<0.05, r=-0.887)$ (Table 1). Therefore, the TN content increased with the decrease in actinomycetes count. This result may be attributed to the TN absorption by actinomycetes. In the future, research should be concentrated on the specific causal mechanism of actinomycetes on TN in soil, as well as concerned about the ratio of actinomycetes in EMs, to retain or improve the content of TN.

\section{Conclusions}

In this study, the EMs containing B. subtilis, B. stearothermophilus, B. amyloliquefaciens, and Actinobacteria sp. were added monthly to kiwifruit planting soil from April to August to investigate the effects of EMs on microbes and nutrients in kiwifruit planting soil. Results show that application of EMs can eventually increase the counts of bacteria, actinomycetes, and fungi in kiwifruit planting soil as well as change the biological diversity of the kiwifruit planting soil ecosystem. Adding EMs to kiwifruit planting soil can reduce soil $\mathrm{pH}$, but the reduction is not obvious, and the $\mathrm{pH}$-values of the EG were still almost neutral. The applied EMs in this study might promote the absorption of major nutrients for kiwifruit tree.

Acknowledgments: This work was supported by the National Natural Science Foundation of China (No. 31400066) and the Scientific Research Innovation Team Project of Sichuan Provincial Department of Education (No. 16TD0006).

Author Contributions: L.F., X.Z., and L.Z. conceived and designed the experiments; L.F. and X.Z. performed the experiments; L.F., X.Z., Y.L., and L.J. analyzed the data; Y.L., G.W., B.L., and W.D. contributed analysis tools; Y.L., L.C., and M.L. contributed reagents and materials; L.F., X.Z., and L.Z. wrote the paper.

Conflicts of Interest: The authors declare no conflict of interest.

\section{References}

1. Gammon, C.S.; Kruger, R.; Minihane, A.M.; Conlon, C.A.; von Hurst, P.R.; Stonehouse, W. Kiwifruitfruit consumption favourably affects plasma lipids in a randomised controlled trial in hypercholesterolaemic men. Br. J. Nutr. 2013, 109, 2208-2218. [CrossRef] [PubMed]

2. Yang, H.; Lee, Y.C.; Han, K.S.; Singh, H.; Yoon, M.; Park, J.H.; Cho, C.W.; Cho, S. Green and gold kiwifruit peel ethanol extracts potentiate pentobarbital-induced sleep in mice via a GABAergic mechanism. Food Chem. 2013, 136, 160-163. [CrossRef] [PubMed]

3. Imeh, U.; Khokhar, S. Distribution of conjugated and free phenols in fruits: Antioxidant activity and cultivar variations. J. Agric. Food Chem. 2002, 50, 6301-6306. [CrossRef] [PubMed]

4. Mattila, P.; Hellström, J.; Törrönen, R. Phenolic acids in berries, fruits, and beverages. J. Agric. Food Chem. 2006, 54, 7193-7199. [CrossRef] [PubMed] 
5. Sârbu, C.; Naşcu-Briciu, R.D.; Kot-Wasik, A.; Gorinstein, S.; Wasik, A.; Namieśnik, J. Classification and fingerprinting of kiwifruit and pomelo fruits by multivariate analysis of chromatographic and spectroscopic data. Food Chem. 2012, 130, 994-1002. [CrossRef]

6. Mikulic-Petkovsek, M.; Schmitzer, V.; Slatnar, A.; Stampar, F.; Veberic, R. Composition of sugars, organic acids, and total phenolics in 25 wild or cultivated berry species. J. Food Sci. 2012, 77, C1064-C1070. [CrossRef] [PubMed]

7. Park, Y.S.; Im, M.H.; Choi, J.H.; Yim, S.H.; Leontowicz, H.; Leontowicz, M.; Suhaj, M.; Gorinstein, S. The effects of ethylene treatment on the bioactivity of conventional and organic growing 'Hayward' kiwifruit fruit. Sci. Hortic-Amst. 2013, 164, 589-595. [CrossRef]

8. Zhou, D.M.; Hao, X.Z.; Wang, Y.J.; Dong, Y.H.; Cang, L. Copper and Zn uptake by radish and pakchoi as affected by application of livestock and poultry manures. Chemosphere 2005, 59, 167-175. [CrossRef] [PubMed]

9. Chen, Z.; Ma, S.; Liu, L.L. Studies on phosphorus solubilizing activity of a strain of phosphobacteria isolated from chestnut type soil in China. Bioresour. Technol. 2008, 99, 6702-6707. [CrossRef] [PubMed]

10. Esitken, A.; Yildiz, H.E.; Ercisli, S.; Donmez, M.F.; Turan, M.; Gunes, A. Effects of plant growth promoting bacteria (PGPB) on yield, growth and nutrient contents of organically grown strawberry. Sci. Hortic-Amst. 2010, 124, 62-66. [CrossRef]

11. Yu, X.; An, M.; Wang, H.; Shen, G.; Tian, S.; Sun, X.; Wang, L. Influence of Bacillus subtilis Bs-15 on the microbial population and functional diversity of microbial communities in the chestnut soil. Ecol. Environ. Sci. 2014, 23, 598-602.

12. Lucy, M.; Reed, E.; Glick, B.R. Applications of free living plant growth-promoting rhizobacteria. Antonie Leeuwenhoek 2004, 86, 1-25. [CrossRef] [PubMed]

13. Wu, S.C.; Cao, Z.H.; Li, Z.G.; Cheung, K.C.; Wong, M.H. Effects of biofertilizer containing N-fixer, P and K solubilizers and AM fungi on maize growth: A greenhouse trial. Geoderma 2005, 125, 155-166. [CrossRef]

14. Cakmakci, R.; Dönmez, M.F.; Erdoğan, Ü. The effect of plant growth promoting rhizobacteria on barley seedling growth, nutrient uptake, some soil properties, and bacterial counts. Turk. J. Agric. For. 2007, 31, 189-199.

15. Ryu, C.; Murphy, J.F.; Reddy, M.; Kloepper, J.W. A two-strain mixture of rhizobacteria elicits induction of systemic resistance against Pseudomonas syringae and Cucumber mosaic virus coupled to promotion of plant growth on Arabidopsis thaliana. J. Microbiol. Biotechnol. 2007, 17, 280-286.

16. Das, K.; Dang, R.; Shivananda, T.N. Effect of biofertilizers on the nutrient availability in soil in relation to growth, yield and yield attributes of Stevia rebaudiana. Arch. Agron. Soil Sci. 2009, 55, 359-366. [CrossRef]

17. Da Silva Oliveira, W.; Stamford, N.P.; Vila Nova da Silva, E.; de Rosalia e Silva Santos, C.E.; Santiago de Freitas, A.D.; Stamford Arnaud, T.M.; Sarmento, B.F. Biofertilizer produced by interactive microbial processes affects melon yield and nutrients availability in a Brazilian semiarid soil. Aust. J. Crop. Sci. 2014, 8, 1124-1130.

18. Zhang, D.; Xu, N.; Nu, M.; Luo, Y.; Li, J.; Liu, T. Technical Specification of Balanced Fertilization by Soil Testing; Ministry of Agriculture of the People's Republic of China: Beijing, China, 2006.

19. Zou, L.; Li, L.; Pan, X.; Tian, G.; Luo, Y.; Wu, Q.; Li, B.; Cheng, L.; Xiao, J.; Hu, S.; et al. Molecular characterization of $\beta$-lactam-resistant Escherichia coli isolated from Fu River, China. World J. Microb. Biot. 2012, 28, 1891-1899. [CrossRef] [PubMed]

20. Soil Science Society of China. Methods of Soil and Agricultural Chemistry Analysis; China Agriculture Scientech Press: Beijing, China, 1999; pp. 147-194.

21. Luo, H.; Liu, X.; Anderson, B.C.; Zhang, K.; Li, X.; Huang, B.; Li, M.; Mo, Y.; Fan, L.; Shen, Q.; et al. Carbon sequestration potential of green roofs using mixed-sewage-sludge substrate in Chengdu World Modern Garden City. Ecol. Indic. 2015, 49, 247-259. [CrossRef]

22. Huang, S.W.; Jin, J.Y.; Yang, L.P.; Bai, Y.L. Spatial variability of soil nutrients and influencing factors in a vegetable production area of Hebei Province in China. Nutr. Cycl. Agroecosyst. 2006, 75, 201-212. [CrossRef]

23. Sand, W. Microbial life in geothermal waters. Geothermics 2003, 32, 655-667. [CrossRef]

24. Pang, X.; Ning, W.; Qing, L.; Bao, W. The relation among soil microorganism, enzyme activity and soil nutrients under subalpine coniferous forest in Western Sichuan. Acta Ecol. Sin. 2009, 29, 286-292. [CrossRef]

25. Yang, J.; Zhou, G.Y.; Tian, Y.Y.; Liu, L.Q.; Liu, C.F.; Yang, Q.; Zhou, J.C. Differential analysis of soil bacteria diversity in different mixed forests of Dalbergia odorifera. Acta Ecol. Sin. 2015, 35, 8117-8127. 
26. Gaind, S.; Gaur, A.C. Effects of $\mathrm{pH}$ on phosphate solubilization by microbes. Curr. Sci. India 1989, 58, 1208-1211.

27. Turan, M.; Ataoglu, N.; Sezen, Y. Effects of phosphorus solubilizing bacteria (Bacillus megaterium) on yield and phosphorus contents of tomato plant (Lycopersicon esculentum L.). In Proceedings of the Third National Fertilizer Congress (Farming-Industry-Environment), Tokat, Turkey, 11-13 October 2004; pp. 939-945.

28. Yan, H.; Guo, S.; Liu, W. Effects of Bacillus subtilis on rhizosphere enzyme activities of cucumber under salt-stress. Acta Agric. Boreali-Sin. 2010, 25, 209-212.

29. Yin, H. Studies on Improving the Capacity of Salt-Tolerance of Cucumber by Bacillus subtilis. Master's Thesis, Nanjing Agricultural University, Nanjing, China, 2006.

30. Walia, A.; Mehta, P.; Chauhan, A.; Shirkot, C.K. Effect of Bacillus subtilis strain $\mathrm{CKT}_{1}$ as inoculum on growth of tomato seedlings under net house conditions. Proc. Natl. Acad. Sci. India Sect. B Biol. Sci. 2014, 84, 145-155. [CrossRef]

31. Shweta, G.; Rajesh, K.; Kirti, K.; Anjali, C.; Singh, S.R. Efficacy of indigenous plant growth promoting rhizobacteria on capsicum yield and soil health. Res. Crop. 2015, 16, 123-132.

32. Li, Y.; Yan, J.; Hou, Q.; Xie, Y. Effects of bacterial manure on soil base dissolving N under different conditions of soil moisture content. J. Changzhi Univ. 2006, 23, 5-7.

33. Ma, Y.; Luo, Y.; Teng, Y.; Li, Z. Plant growth promoting rhizobacteria and their role in phytoremediation of heavy metal contaminated soils. Acta Pedol. Sin. 2013, 50, 1021-1031.

34. Mantelin, S.; Touraine, B. Plant growth-promoting bacteria and nitrate availability: Impacts on root development and nitrate uptake. J. Exp. Bot. 2004, 55, 27-34. [CrossRef] [PubMed]

35. Hameeda, B.; Harini, G.; Rupela, O.P.; Wani, S.P.; Reddy, G. Growth promotion of maize by phosphate solubilizing bacteria isolated from compost and microfauna. Microbiol. Res. 2008, 163, 234-242. [CrossRef] [PubMed]

36. Richardson, A.E.; Barea, J.M.; McNeill, A.M.; Prigent-Combaret, C. Acquisition of phosphorus and nitrogen in the rhizosphere and plant growth promotion by microorganisms. Plant Soil 2009, 321, 305-339. [CrossRef]

37. Kumar, A.; Maurya, B.R.; Raghuwanshi, R. Isolation and characterization of PGPR and their effect on growth, yield and nutrient content in wheat (Triticum aestivum L.). Biocatal. Agric. Biotechnol. 2014, 3, 121-128. [CrossRef]

38. Idriss, E.E.; Makarewicz, O.; Farouk, A.; Rosner, K.; Greiner, R.; Bochow, H.; Richter, T.; Borriss, R. Extracellular phytase activity of Bacillus amyloliquefaciens FZB45 contributes to its plant-growth-promoting effecta. Microbiology 2002, 148, 2097-2109. [PubMed]

39. Liu, P. Impact of Bacillus amyloliquefaciens and Phosphorus in Rhizosphere on the Growth and P uptake of maize. Master's Thesis, Jilin University, Jilin, China, 2013. 